\title{
SHOULD CANADA'S FOREIGN AID POLICY HELP ADDRESS THE ENVIRONMENTAL IMPACT OF SINGLE-USE PLASTICS?
}

\author{
RILEY E.J. SCHNURR, TONY R. WALKER* \\ School for Resource and Environmental Studies, Dalhousie University, \\ Halifax, NS, B3H 4R2, Canada
}

The international community, including those from governments to environmental non-governmental organizations and from individuals to corporations, have been inundated recently with talk about the environmental impacts of single-use plastics (SUPs) - especially plastic shopping bags and straws (Schnurr and Walker 2018). In Nova Scotia, marine debris collected as part of the Great Canadian Shoreline Cleanup included SUP items such as cigarette butts, food wrappers, plastic bottle caps, straws/stirrers, and plastic beverage bottles, which broadly mirror those across the rest of Canada. In addition, there were plastic fishing ropes and strapping bands (Pettipas et al. 2016). Microplastic fibers have also been found in intertidal sediments and blue mussels in Halifax Harbour (Mathalon and Hill 2014), and in most seawater grab samples collected in an ongoing study near Lunenburg (CBC News 2018).

Canada's Presidency at the 2018 G7 in Charlevoix had reducing marine plastic pollution, as one (of five) themes in "Working together on climate change, oceans and clean energy" (Government of Canada 2018; Ocean Plastics Charter 2018). After the June G7 meeting, all but two G7 leaders (including the European Union as one whole) committed to, among other announcements, an Ocean Plastics Charter (Japan and the US did not sign on, albeit for vastly different reasons) (Ocean Plastics Charter 2018). In democratic and bureaucratic fashion, the Plastics Charter contains five working areas, each with between two and six commitment actions. All are geared towards "[taking] action toward a resource-efficient lifecycle management approach to plastics in the economy" (Ocean Plastics Charter 2018). The plan is to move towards zero plastic waste, by reducing and recycling SUPs (Walker and Xanthos 2018). This is an admirable endeavour - getting some of the largest economies in the

* Author to whom correspondence should be addressed: trwalker@dal.ca 
world, committing to invest in research and development, to engage with industries or other stakeholders, and to encourage interventions that change linear plastics consumption habits. Developing strategies to be less wasteful is no small task.

Developing economies contribute much more to the global plastics problem than $\mathrm{G} 7$ countries and so there seems to be a dissonance that goes unacknowledged. A study by Jambeck et al. (2015) highlighted the fact that developing economies, especially those in Asia and Southeast Asia, are the top plastic ocean polluters. China, Indonesia, Philippines, Thailand and Vietnam are the top producers of plastic waste (Jambeck et al. 2015). This is caused in part by a booming middle-class consumer population and increasing standards of living, yet waste management infrastructure (or environmental regulation, policy, or societal behaviour) has not kept pace. Furthermore, China was the largest global importer of plastic waste, mostly from developed countries (Liu et al. 2018; Walker 2018a). Finally, these countries also have long coastlines, allowing plastic pollution to leak into the oceans or to become stranded along the coast.

The value of SUP interventions in economies that, on a global scale contribute very little marine plastic pollution to the oceans have been hotly debated (Xanthos and Walker 2017; Knoblauch et al. 2018; Schnurr et al. 2018). This does not mean that a Canadian plastic straw ban or an Australian plastic bag ban are ineffective, but it does highlight that interventions differ between jurisdictions (Schnurr et al.2018). Like others, we believe that this is crisis worthy of global intervention (e.g., Borrelle et al. 2017; Dauvergne 2018; Walker 2018b). Some international development, foreign aid, and NGOs have historically and traditionally been fraught with imperial and self-serving attitudes resulting in ineffective, interventions by rich economies onto poor economies under the guise of 'assistance'. Contemporary iterations have focused on the environment even though it is increasingly recognized that the impact of climate change is felt by different people from those that are significantly more 'responsible' for contributing to the problem.

Developed nations like Canada, invest heavily in climate change mitigation (such as international carbon market trading) via our foreign aid. Should we also be investing in mitigating plastic polluters in other countries if we are not the ones throwing our plastic wrappers into the oceans (European Commission 2018)? Does our answer to this question change when we know that developed economies send 
their plastics waste to developing economies (Brooks et al. 2018; Liu et al.2018)? The answers depend on your ethical, social, and moral stance. In theory, one could argue there is enough reason to avoid feeling guilty for marine plastic pollution given Canada's small contributions. Environment and Climate Change Canada estimates that Canada 'leaked' only about 8,000 metric tonnes of plastic into our freshwater and marine waterways in 2010. Canada is in the low-range category of mismanaged waste 'able' to enter the oceans, at around 0.01 0.25 million metric tonnes (Jambeck et al. 2015). However, wiping one's hands clean and walking away because "I'm not at fault" is a case of the tragedy of the commons in effect on our oceans - it becomes selective environmental activism that makes for a poor ally for the earth. Indeed, of the eight billion tons of plastic produced in the last fifty years, only $9 \%$ has been recycled and $12 \%$ incinerated, leaving the remainder in landfills or finding its way into lakes, rivers or the Ocean (Geyer et al. 2017).

What should this mean for Canada, that has just held the G7 Presidency, and for our future international obligations? Canada should show strong environmental leadership on the international stage when reconsidering international development priorities, programming, or strategic engagements. Global Affairs Canada can and should consider assisting funding waste management infrastructure in places where the gap between social development and said infrastructure is highest (Liu et al.2018; Oceans North 2018). In the same way that Canadian foreign aid helps build wells and schools in developing countries, we must contribute to the development of a global circular economy with respect to plastics (Walker and Xanthos 2018). Currently, many of the innovations and technologies that could promote the transition to a circular plastics economy stem from non-developed nations (Liu et al.2018). Opportunities for mutual learning and knowledge transfer are calling to us.

Canada's international engagements, including the G7, but at other bilateral or multilateral fora as well, could provide great avenues to advance an anti-SUP agenda (like the Ocean Plastics Charter). The aim should neither ignore the more glaring sources of marine pollution nor makes Canada an environmental hypocrite and in fact, the Charter already makes mention of this (Ocean Plastics Charter 2018). Two key points in the Charter commit developed economies to target the most significant contributors to the marine plastic pollution problem, and to assist populations that are the most vulnerable (these 
two groups are often not the same). Environment Minister Catherine McKenna was optimistic the Ocean Plastics Charter could be a 'Paris Agreement for plastics'. The Canadian leadership has spoken and has latched onto plastics as the eco-campaign of 2018. Now Canada needs to walk the talk.

\section{REFERENCES}

Borrelle, S.B., Rochman, C.M., Liboiron, M., et al. (2017). Opinion: why we need an international agreement on marine plastic pollution. Proceedings of the National Academy of Sciences 114(38): 9994-9997.

Brooks, A.L., Wang, S., \& Jambeck, J.R. (2018). The Chinese import ban and its impact on global plastic waste trade. Science Advances 4(6): eaat0131.

CBC News. (2018). Tiny pieces of plastic easy to find in vast Atlantic waters. www.cbc.ca/news/canada/nova-scotia/microplastics-microfibremicrobeads-study-atlantic-canada-ocean-1.4813636

Dauvergne, P. (2018). Why is the global governance of plastic failing the oceans? Global Environmental Change 51: 22-31.

European Commission. (2018). International carbon market. Retrieved from https://ec.europa.eu/clima/policies/ets/markets_en

Geyer, R., Jambeck, J.R., \& Law, K.L. (2017). Production, use, and fate of all plastics ever made. Science Advances 3(7): e1700782.

Government of Canada. (2018). Working together on climate change, oceans and clean energy. Retrieved from https://pm.gc.ca/eng/news/ 2018/06/10/working-together-climate-change-oceans-and-clean-energy

Jambeck, J.R., Geyer, R., \& Wilcox, C., et al. (2015). Plastic waste inputs from land into the ocean. Science 347(6223): 768-771.

Knoblauch, D., Mederake, L., \& Stein, U. (2018). Developing Countries in the Lead-What Drives the Diffusion of Plastic Bag Policies? Sustainability 10(6): 1-24.

Liu, Z., Adams, M., \& Walker, T.R. (2018). Are exports of recyclables from developed to developing countries waste pollution transfer or part of the global circular economy? Resources Conservation and Recycling 13: 22-23.

Mathalon, A., \& Hill, P. (2014). Microplastic fibers in the intertidal ecosystem surrounding Halifax Harbor, Nova Scotia. Marine Pollution Bulletin 81(1): 69-79.

Oceans North. (2018). Informing Canada's G7 Presidency. Retrieved from oceansnorth.org/wp-content/uploads/2018/09/G7-PlasticsReport_FINAL.pdf

Ocean Plastics Charter. (2018). Ocean Plastics Charter. Retrieved from g7.gc.ca/wp-content/uploads/2018/06/OceanPlasticsCharter.pdf 
Pettipas, S., Bernier, M., \& Walker, T.R. (2016). A Canadian policy framework to mitigate plastic marine pollution. Marine Policy 68: 117-122.

Schnurr, R.E.J., \& Walker, T.R. (2018). Why you shouldn't be a 'strawman' environmentalist. The Conversation. Retrieved from the conversation.com/why-you-shouldnt-be-a-straw-man-environmentalist100303

Schnurr, R.E.J., Alboiu, V., \& Chaudhary, M., et al. (2018). Reducing marine pollution from single-use plastics (SUPs): A review. Marine Pollution Bulletin 137: 157-171.

Walker, T.R. (2018a). China's ban on imported plastic waste could be a game changer. Nature 553(7689): 405-405.

Walker, T.R. (2018b). Drowning in debris: solutions for a global pervasive marine pollution problem. Marine Pollution Bulletin 126: 338.

Walker, T.R., \& Xanthos, D. (2018). A call for Canada to move toward zero plastic waste by reducing and recycling single-use plastics. Resources, Conservation and Recycling 133: 99-100.

Xanthos,D., \& Walker,T.R.(2017). International policies to reduce plastic marine pollution from single-use plastics (plastic bags and microbeads): a review. Marine Pollution Bulletin 118(1-2): 17-26. 
